\title{
The course of the obturator artery following passage through the obturator foramen into the thigh
}

\author{
Ali Navi, ${ }^{1}$ Eleanor Jane $\mathrm{H}$ Turner, ${ }^{2}$ Rachel Claire Aland ${ }^{3}$ \\ ${ }^{1}$ University College London, London, UK; \\ ${ }^{2}$ Surgery Department, Epsom General Hospital, Epsom, UK; \\ ${ }^{3}$ Anatomy Department, St George's Hospital, London, UK \\ Correspondence to Miss Eleanor Jane H Turner, ejhturner@yahoo.com
}

\section{DESCRIPTION}

The variability of the obturator artery inside the pelvis is well known; however in the thigh only two branches encircling the obturator foramen are described. With the evolution of minimally invasive trans-obturator approaches to pelvic surgery the anatomy in this area needs to be better understood. Trans-obturator approach has been shown clinically more effective and less invasive treatment for
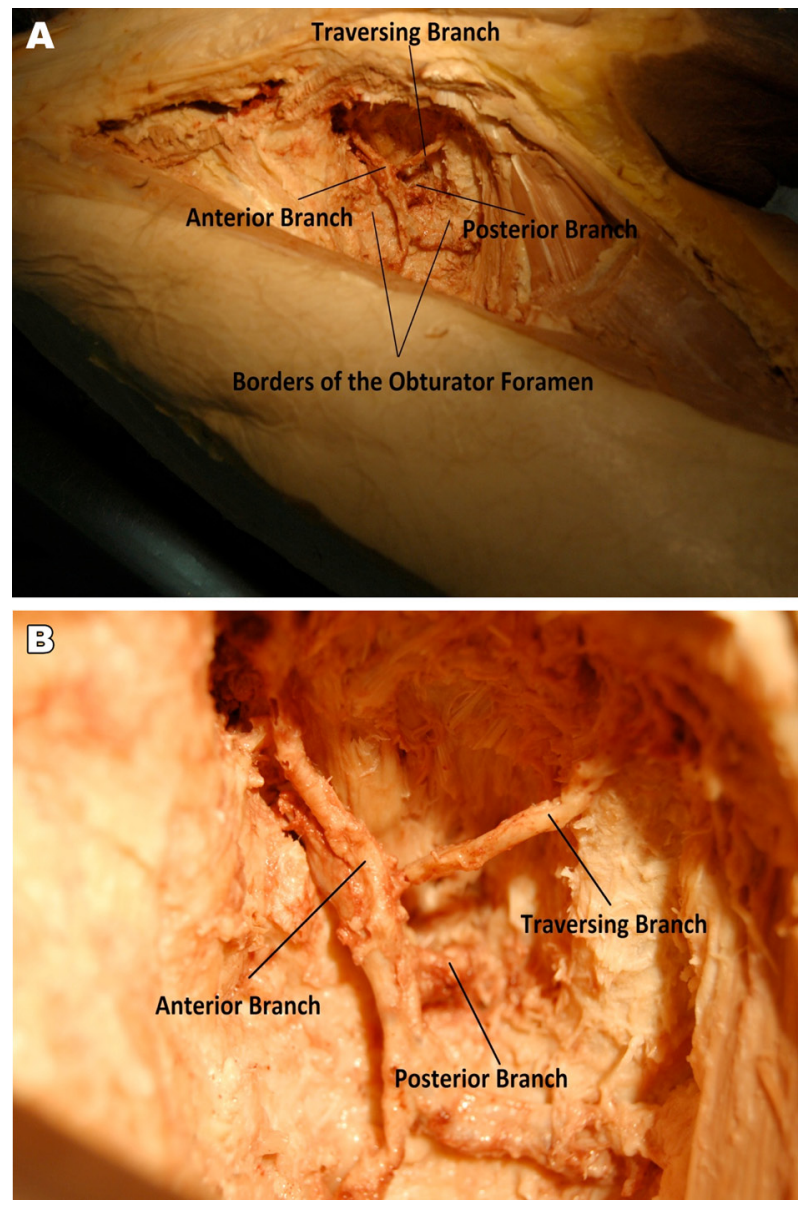

Figure 1 Photograph of dissection illustrating the right femoral triangle (A) from a distance, (B) close-up. urinary stress incontinence ${ }^{12}$; however it may be associated with vascular complications. ${ }^{3}$ To describe, confirm and measure the branches of the obturator artery following passage through the obturator foramen using a single human cadaver, dissection of the course of the obturator artery from its passage through the obturator foramen in the right groin was performed (figure 1). Vessels were measured with calipers and the branching patterns described. The obturator artery was identified piercing the obturator fascia at 7o' clock position giving off posterior and anterior branches (2.7 $\mathrm{mm}$ and $1.9 \mathrm{~mm}$ in diameter, respectively) encircling the foramen measuring 2.7 by $5.2 \mathrm{~cm}$. There was a traversing branch (1.7 $\mathrm{mm}$ in diameter) coming off the posterior branch $1.7 \mathrm{~cm}$ above the inferior border of the foramen. This branch passed the foramen medially 3.2 $\mathrm{cm}$ above the inferior border of the foramen. This study reveals that traversing branches of obturator artery are potentially at risk of injury during the trans-obturator surgical approach. Further dissections are required to understand how frequent this is.

\section{Learning points}

- Traversing branches of obturator artery are potentially at risk of injury during the trans-obturator surgical approach.

- Further dissections are required to understand how frequent this is.

\section{Competing interests None.}

Patient consent Not obtained.

\section{REFERENCES}

1. Barry C, Lim YN, Muller R, et al. A multi-centre, randomised clinical control trial comparing the retropubic (RP) approach versus the transobturator approach (TO) for tension-free, suburethral sling treatment of urodynamic stress incontinence: the TORP study. Int Urogynecol J Pelvic Floor Dysfunct 2008;19:171-8.

2. Morey AF, Medendorp AR, Noller MW, et al. Transobturator versus transabdominal mid urethral slings: a multi-institutional comparison of obstructive voiding complications. J Urol 2006;175:1014-7.

3. Rajan S, Kohli N. Retropubic hematoma after transobturator sling procedure. Obstet Gynecol 2005;106:1199-202. 


\section{BMJ Case Reports}

This pdf has been created automatically from the final edited text and images.

Copyright 2012 BMJ Publishing Group. All rights reserved. For permission to reuse any of this content visit http://group.bmj.com/group/rights-licensing/permissions.

BMJ Case Report Fellows may re-use this article for personal use and teaching without any further permission.

Please cite this article as follows (you will need to access the article online to obtain the date of publication).

Navi A, Turner EJ, Aland RC. The course of the obturator artery following passage through the obturator foramen into the thigh. BMJ Case Reports 2012;10.1136/bcr.02.2012.5898, Published XXX

Become a Fellow of BMJ Case Reports today and you can:

- Submit as many cases as you like

- Enjoy fast sympathetic peer review and rapid publication of accepted articles

- Access all the published articles

Re-use any of the published material for personal use and teaching without further permission

For information on Institutional Fellowships contact consortiasales@bmjgroup.com

Visit casereports.bmj.com for more articles like this and to become a Fellow

Keep up to date with all published cases by signing up for an alert (all we need is your email address) http://casereports.bmj.com/cgi/alerts/etoc 